\title{
Protection of Privacy in Designing of Residential Complexes Architecture and Its Effect on Constructive Relations among the Residents
}

\author{
Shirin Javanshir ${ }^{1}$ \\ ${ }^{1}$ Master (MA), Architectural Engineering, Islamic azad University, Mashhad, Iran \\ Correspondence: Shirin Javanshir, Master (MA), Architectural Engineering, Islamic azad University, Mashhad, \\ Iran.
}

Received: September 9, 2015

Accepted: September 19, $2015 \quad$ Online Published: December 22, 2015

doi:10.5539/mas.v10n1p103

URL: http://dx.doi.org/10.5539/mas.v10n1p103

\begin{abstract}
Abode is the most important provider of civilization and house is the best protection of social culture of the society. Abode is the protector of the family dynasty and the relations among its members. Having suitable abode like other human needs is one of the primary rights of humans and it has been emphasized in constitutional law (article thirty one). Lack of abode and its unsuitable quality has direct and close relation with increasing of delinquency, divorce and social disruption and it is accounted as a deterrent factor in social, cultural and mental development and moderation. Also not having abode causes to create the social abnormal phenomena such as sleep street, hutment and slum that such life gives abnormal personality structure to the person. Lack of abode or its unsuitable quality is accounted an effective factor in creating phenomena like anxiety, depression and behavorial disorders and causes to decrease the mental and physical resistence of the person in facing with problems. Therefore planning for protection of privacy and residents independency despites the existence of healthy and constructive social interactions in residential complexes is an important thing. The purpose of this research is discussing about the importance of constructive privacy existence in residential complexes and the manner, quality and effective factors in formation of it. In order to promote the research, descriptive-analytic methodology has been applied and the method of information collecting is in the kind of documentary study which is embarked to analyze the received information by using of qualitative contents analysis.
\end{abstract}

Keywords: privacy, residential complex, architecture, residents

\section{Introduction}

One of the significant problems of today societies is the existence of threats and dangers that daily and in urban spaces affects on citizens. This issue becomes more problem-making when the persons in their daily life space namely in their residence location face with behaviors that cause lack of their security feeling in spaces in which they should be comfortable and with their family use of those spaces freely (Jahanshahlou, Andelib, \& Zarabian, 2010). Existence of secure environment for living beside other significant physiologic needs of human like food, shelter and hygiene is one of the necessities of human life. 

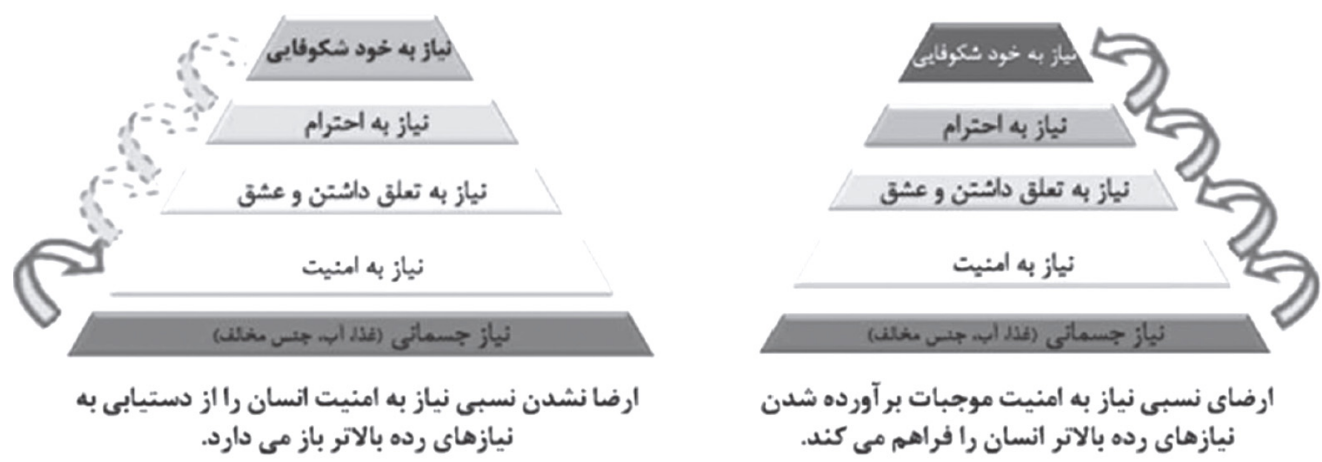

Figure 1. The position of need to security in hierarchy of Mazlou needs and the effect of lack of this need fulfillment on other needs of human (Akbari \& Pakbonyan, 2012)

Unfulfilled need for human security in public spaces not only prevent him from reaching to higher rank needs like self-actualization, aesthetic, knowing and understanding but also leads to decrease social interactions and finally emptiness of public spaces (Akbari \&Pakbonyan, 2012).

House is one of the locations that becomes the provider of need to respect, having fixation, physical needs, self-actualization and security in human. In Islam and Quran verses, the importance and position of residential house for achieving mental and spiritual comfort have been especially emphasized. The most important result of comfort is purity and spirituality of a house's space, the ability of providing and responding to the spiritual and mental needs of human like thought, presence and comfort of heart. The true religion of Islam proposes significant specifications and characteristics in house for preventing from any kind of extremes in this issue and discourages its followers from any kind of extremes (renovation organization of Tehran city). Now this key question is proposed that why in the true religion of Islam and prophets' and Imams' sayings, the importance of the house has been emphasized to this extent, and in its necessity it is enough that selling it is abominable even for paying debt to another:

Seek refuge to God from that you deport him of his shelter-Imam Sadegh (peace be upon him). (Note 1)

House as the most important arena of residence in traditional architecture of Iran has been constituted of different elements that location-finding of them to the neighboring houses and public arena had been provider of a space with privacy for them. One of the most important elements that has significant role to create confidentiality by being located in the link location of private and public arena (Alialhesabi \& Ghorbani, 2014). One of the most important rules which has been considered in traditional architecture of Iran especially after Islam is confidentiality rule which has been applied in the best state in all buildings from public huge ones to residential houses and from urban public spaces to semi-public and more private spaces.

It can be said that in urbanism and Islamic architecture from hugest urban spaces to the smallest architecture spaces have been affected by confidentiality rule (Seyfian \& Mahmoudi, 2007). During the circumstances for reaching to the perfection, the Moslems have been always considered in religious and gnostic culture. In monotheistic worldview, a perfectionist look has been taken to the human and this world has been figured as transition stages toward ultimate perfection (Nasr, 2005) (Tabasi \&Fazelnasab, 2012).

Privacy creates boundary and doesn't mean separation, rather it is effective in all affairs of life, social relations and following it in architecture and while it creates a veil, prevents from others transgression and protects from the life integrity. Privacy is the protector of the persons' solitude so that the possibility of excursion in inside states is achieved and balance is created between outside and inside (Jabal Ameli, 1995).

According to that, this article follows to study the role of protection from privacy on security rate of residential houses residents and finally designing.

\section{The Research Background}

There are three points of view about this issue that whether architecture can be effective on the human' $\mathrm{s}$ behavior or not. The first point of view which is named environmental algebraic view, states that architecture directly forms the behavior of persons who are in that environment. The second point of view or environmental optional view believes that: the environment supplies the behavioral opportunities and it is also the factor of 
creating the potential limitations of behavior. It is unlikely that environment causes to appear a behavior or decision, and make it inevitable. Environmental optional view doesn't know the environment the only determiner of behavior, rather knows it a field for occurring the behavior and in short, the human's behavior is the common product of environment and his choices. Also the third point of view which is environmental eventual view, such expresses: than an organization in each environmental situation may choose different responds. But each decision or special behavior has a degree of eventuality.

If three above points of view have been studied about privacy briefly, it should be said that even if the eventuality of architecture effect is considered for the behavior of humans; with regard to the importance of private space and its privacy for persons, it can be a good justification for taking effect of the spaces designing with regard to the category of the human's privacy. If this effect is also so little, it can be effective in the relation between humans. For example, when a door is transparent and vitreous, all pass of it without pause. But if the same door is considered non-transparent, on arrival the persons with little pause will knock the door and then enter. Of course this issue should be added to the above cases that whatever the space designing is closer to the demands and culture of people and the architecture is more successful, it will have also more directing role. In this order that each architecture that creates more secure and better privacy for the humans is more successful and its effect on the behavior of people will be more and it will have more shares in promotion of their social level.

Table 1. Definitions of solitude concept from the theorists' view (Altman, 2003)

\begin{tabular}{|c|c|}
\hline Theorists & The definitions of solitude concept \\
\hline Esvarence & A thing except withdrawal from crowd and tendency to seclusion \\
\hline Zimel, 1950 & $\begin{array}{l}\text { Controlling the received motives from others, information rate and the persons distance } \\
\text { from each other }\end{array}$ \\
\hline Chapin, 1951 & The value of staying alone and comfort from the others presence pressure \\
\hline Bites, 1964 & $\begin{array}{l}\text { This feeling of person that the others should be separated and away from what is important } \\
\text { for him and meanwhile acknowledging to this point that the others also have a right from } \\
\text { that thing. }\end{array}$ \\
\hline Jourar,1966 & $\begin{array}{l}\text { The result of the person's tendency to keep secret his past and present experiences and his } \\
\text { purposes for future. Tendency to be mystery for others, or the state which is more } \\
\text { common, tendency to control the others' opinion and belief about himself }\end{array}$ \\
\hline $\begin{array}{l}\text { Inlson, } \\
\text { Proushanski, } \\
\text { Riolin, } 1970\end{array}$ & $\begin{array}{l}\text { Reaching and freedom of choice and determining the necessary purposes for supervision } \\
\text { on this issue that we transfer what information about ourselves }\end{array}$ \\
\hline Rapapourt, 1972 & $\begin{array}{l}\text { The ability of supervision on interaction, having the right of choice and necessary } \\
\text { arrangements and mechanisms for preventing from unwanted interaction and reaching to } \\
\text { desired relation }\end{array}$ \\
\hline Altman, 2001 & $\begin{array}{l}\text { Farness and closeness of person to the others and freedom of choice about relation with } \\
\text { others }\end{array}$ \\
\hline
\end{tabular}

\section{Methodology}

Methodology is the instrument or the method of determining this thing that how a proposition of a research is confirmed or rejected? In other words, methodology provides the operation frame or exploratory paces for fulfillment of the research purpose in order to test the hypothesis or responding to the research questions (Bazargan and others).

In this research, the applied methodology is in the kind of descriptive- analytic and the method of information collecting is in the kind of library, field and survey. In this method, the researcher has been used of his most important tool namely taking note and with referring to all identified sources from before, he has written the important and necessary issues in the research notes of course with exact mentioning of the used source and then the received information has been analyzed by using of observation tool and interview in environment and finally the method of qualitative contents analysis.

\section{The Research Questions}

In order to do the obtained research, at first the questions related to the considered issue were proposed to spread the research based on these questions and achieve the intended purposes. These questions are as follows: 
How is the role of protection from privacy in architecture designing?

What factors have role in increasing the privacy and security in residential complexes?

How the causes of social interactions of residents can be provided while protection from privacy?

\section{Findings and Discussion}

In Moien Persian education dictionary, the privacy word has been interpreted to "the around and environs of house" and "a location that supporting and defending of it is essential". From Islam point of view, a family is known ideal that the privacies and limitations are observed among the members according to the divine wise commands (Keyhan, 2014). Confidentiality in architecture and urbanism space is to give body to the space in a manner that has privacy from two bodily and meaning aspects. Having privacy in the domain of special body is more concentrated on the rules that will form the space security and in the domain of meaning, it is the characteristics that present the respect and value for the architecture space in a manner that the person in it reaches to comfort (Seyfian \& Mahmoudi, 2007).

If social psychology is defined studying the manner of people's interaction with each other or the effect of real or implicit presence of others on thoughts, feelings, behavior and purposes of people (Fergas, 1947), each current model of human behavior in interaction with abode needs desired level of individual relation to social interactions. Solitude as a kind of this relation is a special character that its presence is seen in abode more than any other location that in proportion with the need of person or persons and also in relation with any activity will have special meaning (Arjmand \& Khani, 2012). Also in traditions, it has been referred to the protection of the abode privacy, as the prophet (peace be upon him) says: "permission to enter to the house should be taken three times and if it is permitted then enter otherwise return". (Note 2) (Note 3)

Also the prophet (peace be upon him) recommended to his followers that not to enter to the abode of others suddenly or secretly: "entrant person should announce to the person in abode that he is entering, as he doesn't like, his mother, sister and daughter in circumstances that they don't like to be seen, he shouldn't also see a person in this form" (Hor Ameli, 1985; Okhovat, 2012).

In traditional architecture of Iran, appearance of hierarchy in architecture in transverse privacy is occurred with geometry of straight, curved and angled lines with two dimensional figures and three dimensional volumes and in longitudinal hierarchy it is formed with figureless void spaces which are formed among the geometric spaces and gives the opportunity of elevation to the hallucination (Khatami, 2011).

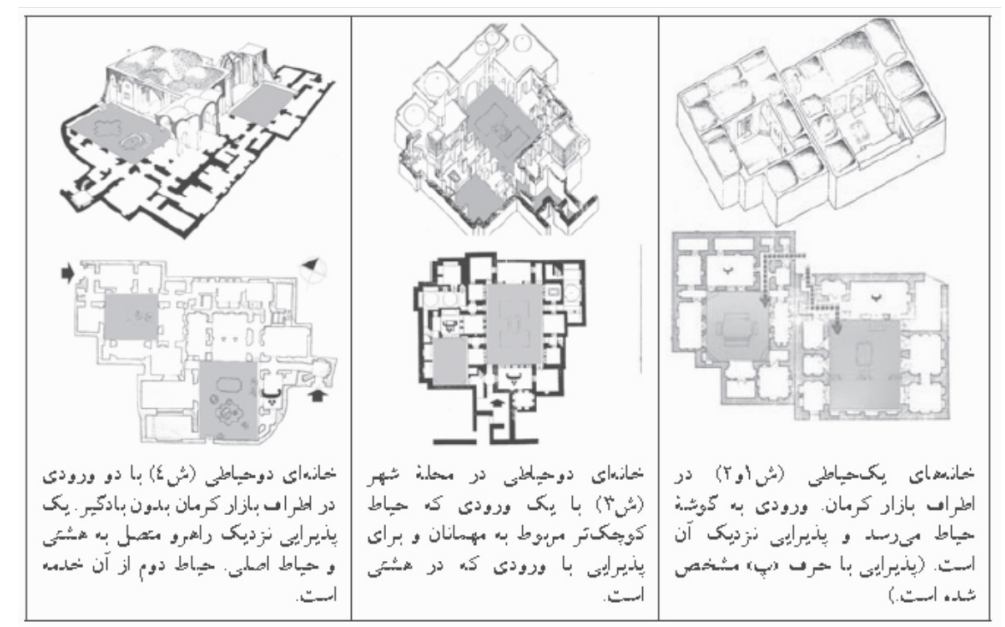

Figure 2. The system of entrance to the house with the purpose of blocking visibility to the inside and respect the privacy (Memarian, Hashemi Toghroljaradi, \& Kamalipour, 2010)

For example in the house of Rasoulian, after passing through a long corridor and semi-dark environment, we reach to the quite light environment (hierarchy of lightness), Also Yazd city. This building in 1904 A. D. coincident with the last years of Ghajar dynasty governorship was constructed thanks to deceased "Haji Mirza Kazem Rasoulian"and with the hand of master "Mohammad Hassan Mohammad Rahim". (Note 4) 
We accede to the yard by two staircases (with difference of three stairs to the passage) and it prepares the person for acceding to a new environment. This issue according to the people-liken rule and respect to the perception of person from environment can be received from norms aspect and social values and religious aspect. The significant point in internal yard is the manner of entering to this yard that is a winding corridor to prevent from direct vision to inside the privacy (religious aspect).

Table 3. Comparing the traditional houses of Moslem, Zoroastrian and Jewish settlement in Kerman city (Memarian, Hashemi Toghroljaradi, \& Kamalipour, 2010)

\begin{tabular}{|c|c|c|c|}
\hline Parishes & $\begin{array}{l}\text { The parish of the city (Moslem } \\
\text { settlement) }\end{array}$ & $\begin{array}{l}\text { Zarbosf (Zoroastrian } \\
\text { settlement) }\end{array}$ & $\begin{array}{l}\text { Dolatkhaneh (Jewish } \\
\text { settlement) }\end{array}$ \\
\hline $\begin{array}{l}\text { The pattern of } \\
\text { reception room }\end{array}$ & $\begin{array}{l}\text { The reception room has been } \\
\text { separated from private domain and } \\
\text { specified with the arrangements of } \\
\text { reception room domain and it has } \\
\text { been separated due to respect the } \\
\text { behavioral patterns of religious law }\end{array}$ & $\begin{array}{l}\text { The reception room has } \\
\text { been separated but due to } \\
\text { the associable things, } \\
\text { reception room is close to } \\
\text { the entrance generally for } \\
\text { reception of non-fellow }\end{array}$ & $\begin{array}{l}\text { Most of the houses have } \\
\text { separated, but simple } \\
\text { reception room }\end{array}$ \\
\hline $\begin{array}{l}\text { The pattern of } \\
\text { privacy }\end{array}$ & $\begin{array}{l}\text { Living and reception rooms have } \\
\text { been separated and sometimes the } \\
\text { outer and inner yards have been } \\
\text { formed, the houses have one, two } \\
\text { and sometimes three yards and } \\
\text { house has two door knockers }\end{array}$ & $\begin{array}{l}\text { Usually three yards, } \\
\text { including one big yard } \\
\text { and two small ones. There } \\
\text { are not outer and inner } \\
\text { patterns, some houses } \\
\text { have two door knockers }\end{array}$ & $\begin{array}{l}\text { The houses have one yard, } \\
\text { the ancient houses which } \\
\text { haven't been changed } \\
\text { have two door knockers }\end{array}$ \\
\hline $\begin{array}{l}\text { The pattern of } \\
\text { facades }\end{array}$ & $\begin{array}{l}\text { Brick working with Tajvidi } \\
\text { geometry, the colors in harmony } \\
\text { with nature }\end{array}$ & $\begin{array}{l}\text { Tajvidi brick working and } \\
\text { sometimes natural } \\
\text { designs, the colors in } \\
\text { harmony with nature }\end{array}$ & $\begin{array}{l}\text { Simple thatch, the colors } \\
\text { in harmony with nature }\end{array}$ \\
\hline Special cases & $\begin{array}{l}\text { The parents's room has been } \\
\text { separated from children's }\end{array}$ & $\begin{array}{l}\text { The special room for } \\
\text { women in childbirth and } \\
\text { separation period }\end{array}$ & $\begin{array}{l}\text { The special room for } \\
\text { women in their separation } \\
\text { period }\end{array}$ \\
\hline Neighborhood & $\begin{array}{l}\text { Not invading to the neighbor's } \\
\text { privacy, generally the edge of roof } \\
\text { is high, no windows facing the alley }\end{array}$ & $\begin{array}{l}\text { Not invading to the } \\
\text { neighbors' privacy, } \\
\text { sometimes the edge of } \\
\text { roof is high, no windows } \\
\text { facing the alley }\end{array}$ & $\begin{array}{l}\text { Not invading to the } \\
\text { neighbors' privacy, the } \\
\text { roofs have short edge, no } \\
\text { windows facing the alley }\end{array}$ \\
\hline Orientation & $\begin{array}{l}\text { The kiblah orientation } \\
\text { (northeast-southwest) }\end{array}$ & Almost eastern-western & $\begin{array}{l}\text { Generally } \\
\text { northeast-southwest }\end{array}$ \\
\hline $\begin{array}{l}\text { The kind of } \\
\text { texture }\end{array}$ & $\begin{array}{l}\text { Concentrated texture with public } \\
\text { and free square and space like } \\
\text { Hosayniyeh and Tekieh }\end{array}$ & $\begin{array}{l}\text { Garden-house with open } \\
\text { space which is inside the } \\
\text { house. The only public } \\
\text { space, central fire-temple } \\
\text { of Kerman }\end{array}$ & $\begin{array}{l}\text { Condensed texture with } \\
\text { the least distance between } \\
\text { the independent houses, } \\
\text { there is not public open } \\
\text { space }\end{array}$ \\
\hline $\begin{array}{l}\text { The joint of } \\
\text { space }\end{array}$ & $\begin{array}{l}\text { Open joint of yard and corridor } \\
\text { joint between the rooms and regular } \\
\text { joint of vestibule }\end{array}$ & $\begin{array}{l}\text { Open joint of yard and a } \\
\text { corridor between the } \\
\text { rooms and regular joint of } \\
\text { vestibule }\end{array}$ & $\begin{array}{l}\text { Only the open joint of } \\
\text { yard }\end{array}$ \\
\hline $\begin{array}{l}\text { The sign of } \\
\text { house }\end{array}$ & $\begin{array}{l}\text { Grand portal with mentioning the } \\
\text { special verses from Holy Quran }\end{array}$ & $\begin{array}{l}\text { Grand portal without } \\
\text { special mention }\end{array}$ & $\begin{array}{l}\text { Almost without portal or } \\
\text { small and simple entrance }\end{array}$ \\
\hline
\end{tabular}

\section{Considering the Privacy from Contemporary Views}

Newman believes that the security of site can be created through creating hierarchy in space, in a manner that public , semi-public, semi-private and private are specified and it is determined that who is authorized to be in which space. If subsidiary divisions create suitable defined spaces about accessibility ways, extra services and entrances, they will become good natural deterrent against wrongdoing. Suitable performance of this mechanism causes to increase the responsibility feeling and the residents caring of their life environment. When the location 
under controlling in the domain of activity and responsibility of persons is recognized, controlling can be done in desired form. In the best stage namely when the residents feel the district under control in their ownership, protection is accomplished quietly. In the circumstances that the environment doesn't have divided space, the numbers of accessibility ways should be limited so that from security aspect, numerous population can pass of them and enough supervision can be exist. These ways should be designed in a manner that can be seen before passing (Cooper, Marcus, Clare, \& Sarkissian, 1986).

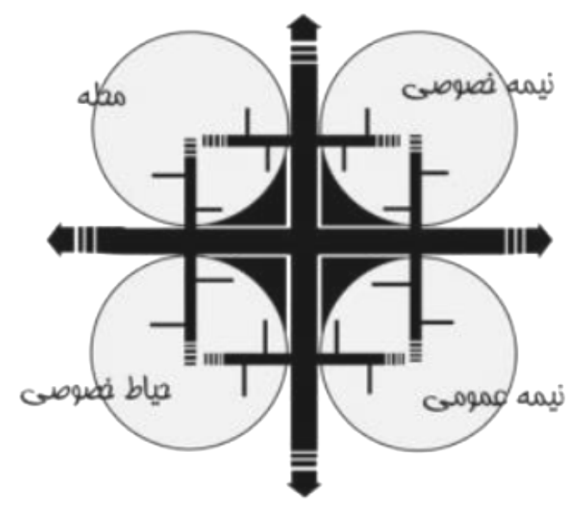

Figure 3. The confidentiality hierarchy system in urban spaces (Tayebian et al, 2012)

\section{Privacy and Realm}

Quintet factors of accessibility, sightedness, neighborhood, sounds and sense of smell are effective on the manner of human's perception from environment and the mechanism that the privacy is controlled by it (Georgiou, 2006). For designing a residential environment with the purpose of creating a defendable space, special division in the form of public, semi-public, semi-private and private spaces will help to recognize this issue that whom are allowed to attend in what space. Privacy and realm is one of the most important provider points of solitude and security. The realm controlling is possible through taking the space by special limitations. Realm can be private (like private open spaces of complex), semi-private like (indoor and outdoor common areas) and public (like the space s of street and sidewalks). Among them the semi-private realm is often ambiguous and it is usually kept weakly (Cooper, Marcus, Clare, \& Sarkissian, 1986).

In order to the optimized and stable performance, in designing of little gardens and neighbors, balance should be created between the privacy existence and creating the interactions among the neighbors. This case is an important aspect of the garden controlling. One of the simplest ways to achieve this purpose is to create a barrier in the size of 1.8 to 2 meter and as privacy in the neighboring of the house that defines the edge of the designing with a relatively short obstacle but firm (Smith, Clayden, \& Dunnett, 2008).

\section{Defendable}

The defendable space from Oscar point of view is a space that gas a low mass capability, in order to reach to this purpose, the spaces should have suitable lighting at night and the spaces which are located in the corner and aren't seen, should be avoided. And also creation of thick green spaces that causes to form a snug location for the residents should be avoided (Samadifard, Movahed, \& Jahanbakhsh, 2013).

\section{Neighborhood and Strengthening the Supervision}

Human has always kept his connection with the society in his life period by helping of relationship. In fact, relationship is accounted one of the most important and tangible elements of social life of human and it is considered one of the significant needs of human. Consequently it is clear that the most suitable person for fulfillment of his need is the closest and more accessible persons namely neighbor. Neighborhood in today large societies has been transformed greatly. In spite of this, it is still considered an important and significant relation, because cultural and technological progress and improvement of each society will need to the presence of humans together and establishment of minimum relationship with each other. The effective factors in neighborhood relations especially about specific form of apartment life and the capability of conversion to active and sincere relations can be stated as follows: (Hester, 1984)

The persons in high social-economic degree have better neighborhood than other groups. 
-the persons who have more free time, have better neighborhood relation

-With increasing of the numbers of children, the neighborhood strength is decreased.

-Existence of homologies like age, job or education causes the closeness of neighbors to each other and better relation establishment.

-Closeness of units to each other causes to increase the neighborhood relations and their separation from each other causes to decrease these relations.

-Strengthening the neighborhood relations through physical structure of high buildings causes to strengthen the supervision of persons on their life environment and create more security that this case can be considered as one of the designing purposes (Bastani, 1990).

\section{The Role of Physical Environment in Visible Districts}

In apartment buildings, the space out of entrance is considered as public space and its responsibility is with the public. The design may be in a form that is divided into many parts and different parts of outer space are controlled by limited persons. Subsidiary divisions should be done with observing the special hierarchy so that the lands are divided among the categories of buildings and each three or four apartments have a common defined space (Rezaee Moghadam, Arzou, Yousef pour, \& Ebadi, 2012).

If the mentioned subsidiary divisions create suitable defined spaces about accessible ways, extra services and entrances, they will become a good natural deterrent against wrongdoing. When the residents feel the under control district in their ownership, protection is done quietly (Challinger, 2008).

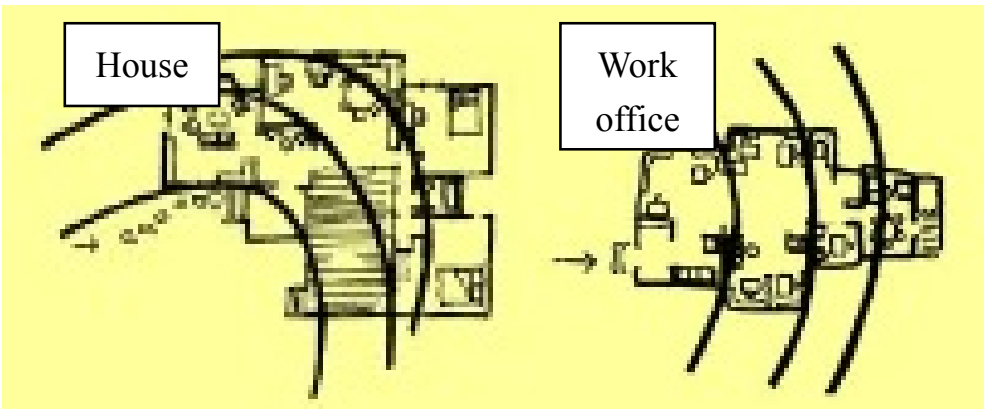

Figure 4. The difference of accessibility layers in a house and work office (Alexander, 1977)

\section{Designing for Protection of Security and Privacy}

Namely protection of building and its residents against the transgressor persons who have the intention of unauthorized entrance to the building and doing the wrong acts. In order to create security, the methods have been recommended for fulfillment of it that of course are different according to the kind of the building performance and its aspects. Designing for organizing a quite security plan should include the total of physical controls and other techniques and control figures (Rezaee Moghadam, Arzou, Yousef pour, \& Ebadi, 2012).

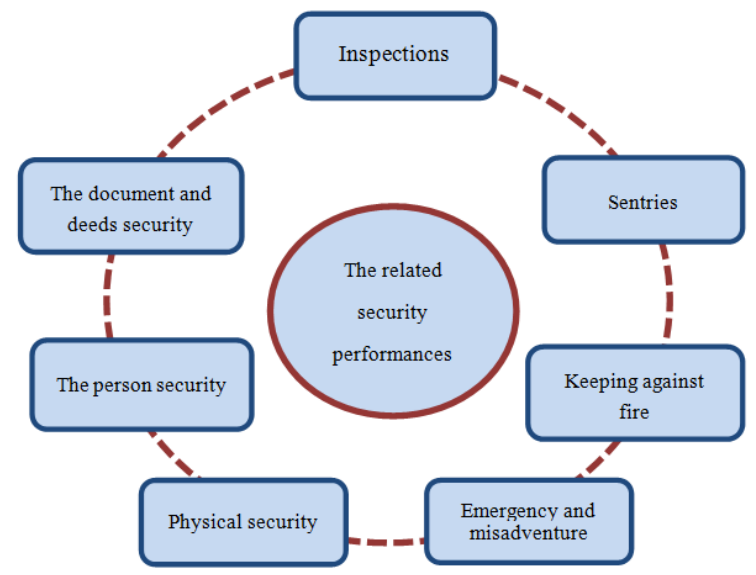

Figure 5. The related security performances (Rezaee Moghadam, Arzou, Yousef pour, \& Ebadi, 2012) 


\section{Indoor Spaces}

Residential buildings have arena and the lands around them have been defined with regard to the special buildings. These defined spaces are good guidance for residents and unknown persons and are used as private spaces by them. The definition of land may be created spontaneously in the circumstances that high apartments are divided into small lands; existence of internal streets strengthens the location security with three following reasons:

1. It prepares direct accessibility to all buildings by automobile.

2. It brings the pedestrian traffic and transport means inside the site limitation and consequently more security is provided by people's presence.

3. It prepares the possibility of control officers cruise and necessary facilities. Also, internal streets are an instrument for identifying the situation of buildings.

The enclosure of a design should be divided in a manner that all its spaces can be related to the specified buildings or building sets, because the lands that have signs based on personal ownership, have more security. The spaces around the building and semi-public open spaces should be designed in a manner that can be seen for residents from inside the building and can create the visibility for sensitive persons, consequently the wrong acts are prevented unconsciously (Talebi, 2004).

\section{Conclusion}

Nowadays with regard to construction of multi-unit complexes, many spaces and performances are transformed and created with a new form. For example, the yard as the private green space has been converted to the public and common space, Staircase, parking, roof and ... as the public and common spaces in building have special specifications which are different with the past life quality. Also when the buildings become multi-floor, the designing of residential spaces of apartment units around the central yard is explainable. It is seen whether from the aspect of accessibility to the floors or economic affairs and construction or the building installations and also control. In addition, the manner of people's life and expectations level and people's habits have been different with the past and a new design should be considered for residential units. By passing the years and doing the repeated experiences, general frame and suitable form with the needs of society have been formed, but this general form despite of being pervasive has deficiencies and difficulties that is not conformed with real cultural and social needs of Islamic Iran Society and it needs acceptable solutions for people. Amongst, paying attention to the private and public arena in designing of residential units and protection of privacy and strengthening the modesty and chastity and lack of betrayal of secrets in residential units are necessary as the center of people's private life and controlling the overlooking.

In a general consideration, the states which are led to create overlooking in buildings (each main and subsidiary design) can be designed like the following diagram.

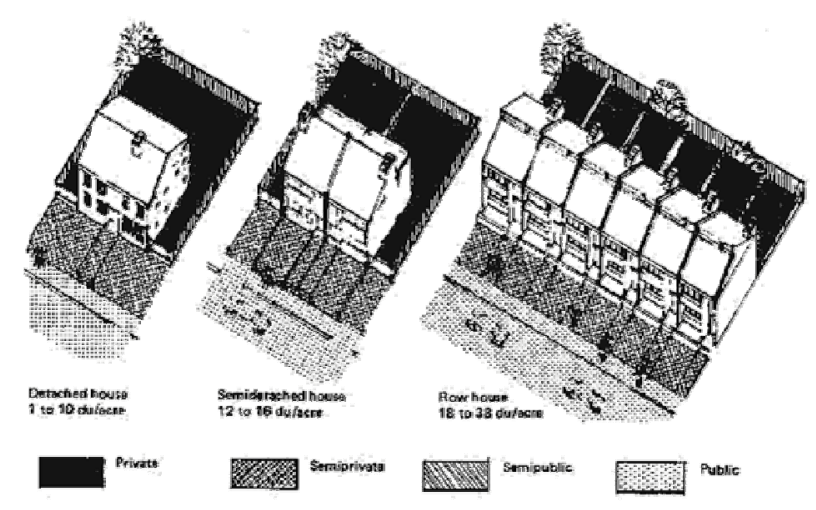

Figure 6. The states of creating the overlooking in buildings (Newman, 1996)

Before considering the ways for prevention from overlooking, another important point is proposed and it is the need and interest to the green and open space in neighboring of residential unit although the residential unit is in the above floors of the building. This natural and innate need of residents can't be ignored. On the other hand, 
constructing the narrow balcony in front of the rooms can't respond to this need. Naturally the persons are interested that attend some moments beside their apartment and open space at the same comfortable and without binding situation that they spend in their unit, especially if a green space is designed in it, it will be more pleasant.

The dimensions of this space should be in a manner that the possibility of the family members gathering, sitting, eating food, children playing and sleeping is feasible in it. On the other hand the perspective of the environment and space shouldn't be a muffled and dreary feeling and really there should be the feeling of open space and in a sense, yard.

On the other hand with regard to the overlooking issue in designing if it is tried that the location of this open space and its dimensions to be in a manner that all spaces of apartment that need light, direct sun and suitable vision can utilize of this space, in this case most of undesired and uncontrolled visions and overlooking are disappeared.

Of course enclosed open spaces in the floors is necessary to prevent from the overlooking of buildings to each other and creating the secure privacy in open space, but attention to the dimensions of walls proportions and the open space enclosure is also important. For this purpose, in free walls of open space, using of the boxes to the little garden, and light fences- like walls, shuttering and brick walls with decorative designs is suggested and minimum height for controlling the vision and overlooking for this complex is the average height of eye. It is suggested that each residential unit has an open space and sky lighting of residential spaces is accomplished from inside the open space. Only the spaces that don't need to direct and much light can have window in the main facade of building.

Definitely, observing this executive regulation has also restrictions such as:

-restriction of the numbers of the buildings' floors

-controlling the advantages, sights and restrictions of vast perspectives

-binding the residential units design to use of open space

-creating the extra cost for constructing the open space in the floors and increasing of finished costs of building

But it should be calculated that these restrictions in the design with the cost of obtaining what facilities have been created. Because principally in the arena of architecture designing, all demands can't be achieved quietly and ideally, rather it is created according to the importance and priority of a balance state among the demands and the optimized state is formed.

\section{References}

Akbari, R., \& Pakbonyan, S. (2012). The effect of public spaces body on social security feeling of women (case sample: Narmak and Ekbatan parishes of Tehran city). Leaflet of beautiful arts-architecture and urbanism, $17(2), 53-64$.

Alexander, C., Ishikawa, S., \& Silverstein, M. (1977). A Pattern Language: Towns, Buildings, Construction. New York: Oxford University Press.

Alialhesabi, M., \& Ghorbani, A. (2014). Considering the specifications of entrance space as visual joint and privacy in neighboring public arenas, case sample: Laft harbor. Journal of Islamic architecture researches, 2(5), 87-108.

Altman, I. (2003). Social environment and behavior: solitude, personal space, realm, and crowd, translation: Namazian, Ali. Editor: Javaher Afsar, the publication center of Shihid Beheshti University, Tehran.

Arjmand, M., \& Khani, S. (2012). The role of solitude in architecture of Iranian house. Journal of Islamic Iranian city studies, 7, 27-38.

Bastani, S. (1990). The neighborhood relations of apartment-settlements of Tehran city. The social sciences college, Tehran University.

Bazargan, A., Sarmad, Z., \& Hejazi, E. (2006). The research methods in behavioral sciences. Tehran: Agah publication.

Challinger, D. (2008). From the Ground Up: Security for Tall Buildings, Connecting Research in Security to Practice, ASIS Foundation.

Cooper, Marcus, Clare, \& Wendy, S. (1986). Housing as if People Mattered. Berkeley: University of California press. 
Fergas, J. (1947). Psychology of social interaction: interpersonal behavior. Translated by Beygi, Khashayar and Firouzbakht, Mehrdad, 1994, Abjad, Tehran.

Georgiou, M. (2006). Architectural Privacy a Topological Approach to Relational Design Problems. Bartlett School of Graduate Studies, University College London.

Hester, R. (Year). Planning Neighborhood Spaces with People, Second Edition. New York, Van Nostrand.

Hor, A., \& Mohammad, E. H. (1985). Translation of vasaeloshiite, Jahadolnafs book, translator: Sehat, Ali, Nas publisher.

Jabal, A. A. (1995). The Esfehan houses in contemporary period, the article sets of congress of architecture and urbanism history. Iran, Arg-e Bam, 4, Cultural Heritage Organization, Tehran.

Jahanshahlou, L., Andelib, A., \& Zarabian, F. (2010). Designing of defendable open spaces in residential parishes of Tehran city, case study: Bagh-e Feiz parish-Pounak, Master Degree thesis, Islamic Azad University, sciences and researches unit, Art and Architecture College.

Khatami, M. (2011). Philosophical prologue on Iranian art, technical edit of Rokni, Abbas, Matin institution for compilation, translation and publication of artistic works, Tehran.

Memarian, G., Hashemi, T. S. M., \& Kamalipour, H. (2010). The effect of religious culture on formation of the house: comparative comparison of house in Moslems, Zoroastrian and jewish parishes of Kerman. Journal of cultural researches, 3(2), 1-25.

Moein, M. (Year). Moein education dictionary. Tehran: Amir kabir publication.

Nasr, S. H. (2005). The aims and realities of Islam, translated by Rahmati, Enshaallah, second edition, Jami, Tehran.

Newman, O. (1996). Creating the defendable spaces, translation: Ravaghi, Faezeh; Saber, Kaveh; Heleh publication.

Okhovat, H. (2013). Comparative consideration of the privacy aspects in traditional and contemporary abode by using of BDSR analytic model.

Rezaee, M. A., Arzou, H., Yousef, P. V., \& Ebadi, M. (2012). Considering the designing position in creating the security feeling in residential complexes. Fourth conference of urban planning and management, Mashhad, Iran. Keyhan (1th October, 2014). Iran: No 20904, page 6.

Samadifard, Z., Movahed, K., \& Jahanbakhsh, H. (2013). Considering the role of common open spaces in today residential comp[lexes as one of the social stability in native architecture up to stable city, Khavaran higher education institution, Mashhad, Iran.

Seyfian, M., \& Mahmoudi, M. (2007). Confidentiality in traditional architecture of Iran. Leaflet of the city identity, 1(1), 3-14.

Smith, C. (2008). Residential landscape sustainability: a checklist tool. Oxford, UK; Malden, MA: Blackwell Pub.

Tabasi, M., \& Fazelnasab, F. (2012). Recognition of role and effect of ,mental proceedings of Safavi era in formation of the mosques entrance of Esfahan School. Leaflet of beautiful arts-architecture and urbanism, 17(3), 81-90.

Tabibian, M. et al. (2012). Reflection of hierarchy rule in Islamic Iranian cities, utopia, No 7.

Talebi, J. (1997). The guidance of designing the architecture of high residential buildings, Tehran, the research center of buildings and abode.

The Holy Quran (1995). The Holy Quran house (the office of history and education studies). Translated by Makarem Shirazi, Naser, Tehran and Ghom.

\section{Notes}

Note 1. Tahzibolahkam, volume 7.

Note 2. Social psychology means an influence that people have on the beliefs and behavior of others.

Note 3. In Sahihin from (Abou Mousa Ashari), it has been mentioned that the messenger of Allah peace be upon him said: (the entrance permission is three friends. If they permit, enter otherwise return). It is recommended that 
an interval as well as four units praying shold be between the first and second permission, lest that the landlord is praying or defecating.

Note 4. The house of Rasoulian is related to the Ghajar period and it is located in Yazd, Sahlebne Ali parish, Martyr Sadoughi alley and this work has been registered in 15th January 1996 with registration number of 1830 as one of the national works of Iran. This house is located in S "ahlebne Ali" parish in the center of the ancient texture of Yazd city. This building in 1904 A. D. coincident with the last years of Ghajar dynasty governorship was constructed thanks to deceased "Haji Mirza Kazem Rasoulia" and with the hand of master "Mohammad Hassan Mohammad Rahim".

\section{Copyrights}

Copyright for this article is retained by the author(s), with first publication rights granted to the journal.

This is an open-access article distributed under the terms and conditions of the Creative Commons Attribution license (http://creativecommons.org/licenses/by/3.0/). 